\title{
Piotr Bukowczyk
}

Towarzystwo Przyjaciół Nauk w Legnicy

\section{Muzułmanie w Polskich Siłach Zbrojnych na Zachodzie}

DOI: $10.19195 / 1643-0328.27 .12$

Słowa kluczowe: muzułmanie, Polskie Siły Zbrojne na Zachodzie, 2. Korpus Polski we Włoszech, Polskie Siły Powietrzne, Jednostki Wojskowe na Środkowym Wschodzie, Samodzielna Brygada Strzelców Podhalańskich, druga wojna światowa, Tatarzy polscy

\section{Wprowadzenie}

Mniejszości wyznaniowe w Polskich Siłach Zbrojnych (dalej: PSZ) na Zachodzie rzadko są przedmiotem badań polskich uczonych. Dosyć dobrze opisani są służący w nich prawosławni. Biogramy Sawy Sowietowa, prawosławnego biskupa polowego PSZ, zamieszczono między innymi w Encyklopedii katolickiej ${ }^{1}$, internetowej wersji Encyklopedii $P W N^{2}$, opracowaniu Krzysztofa Kryski-Karskiego i Stanisława Żurawskiego ${ }^{3}$. Krzysztof Filipow i Andrzej Suchcitz napisali o nim całą książkę ${ }^{4}$. Dziejami podległego mu duszpasterstwa i żołnierzy zajmowali się również Zbigniew Werra ${ }^{5}$ i Norman Davies ${ }^{6}$, opisano je także na stronie internetowej Prawosławnego Orydnariatu Wojska Polskiego, wykorzystując zapewne dane zawarte w niepublikowanej rozprawie doktorskiej Eugeniusza Bój$\mathrm{ko}^{7}$. Ewangelikom w PSZ spore fragmenty swych książek poświęcili Jarosław Kłaczkow ${ }^{8}$

${ }^{1}$ H. Paprocki, Sawa Sowietow, [hasło w:] Encyklopedia katolicka, t. 18, Lublin 2013, kol. 642.

2 Sawa, https://encyklopedia.pwn.pl/haslo/Sawa;3972696.html (dostęp: 27.11.2019).

3 K. Kryska-Karski, S. Żurawski, Generałowie Polski niepodległej, Warszawa 1991, s. 160.

${ }^{4}$ K. Filipow, A. Suchcitz, Arcybiskup generał brygady Sawa (Sowietow), Białystok-Warszawa 1997.

5 Z. Werra, Działalność duszpasterska w 2. Korpusie Polskich Sił Zbrojnych na Zachodzie gen. Władysława Andersa 1941-1947, Warszawa 2009, s. 205, 212.

6 N. Davies, Szlak nadziei. Armia Andersa. Marsz przez trzy kontynenty, przeł. A. Zych, I. Zych, Izabelin-Warszawa 2015, s. 260.

7 Prawosławny Ordynariat Wojska Polskiego. Historia, http://prawoslawnyordynariat. wp.mil.pl/pl/18. html (dostęp: 24.03.2019); Cywilno-Wojskowa Parafia św. Cyryla i Metodego we Wrocławiu. Duchowieństwo. Ks. mitrat płk dr Eugeniusz Bójko, http://cerkiewpiaski.wroclaw.pl/?page_id=141 (dostęp: 24.03.2019).

8 J. Kłaczkow, Na emigracji. Losy polskiego wychodźstwa ewangelickiego w XX wieku, Toruń 2013, s. 57$83,151-162$. 
i Z. Werra ${ }^{9}$. W Encyklopedii katolickiej znajduje się biogram szefa duszpasterstwa ewangelickiego w PSZ, pastora Adolfa Fierli ${ }^{10}$. Jego następcy, Andrzejowi Wantule, poświęcono hasło w Wielkiej encyklopedii PWN ${ }^{11}$. Nieco mniej wiemy o Żydach w PSZ, chociaż wspominają o nich gen. Władysław Anders ${ }^{12}, \mathrm{~N}$. Davies ${ }^{13}$ i Z. Werra ${ }^{14}$. Najgorzej opisaną mniejszością religijną w PSZ są muzułmanie. Bardzo krótkie informacje o nich znajdziemy w publikacjach gen. Andersa ${ }^{15}$, Daviesa ${ }^{16}$ i Werry ${ }^{17}$. Pomocne przy poszukiwaniach informacji o wyznawcach islamu w PSZ są portale internetowe https://niebieskaeskadra. pl/, http://polskiecmentarzewewloszech.eu/, http://www.polskicmentarzbolonia.pl i Wikipedia, na których zamieszczono zdjęcia grobów. Słownik biograficzny Tatarów polskich w XX wieku pod redakcją Aleksandra Miśkiewicza (Białystok 1438/2016), książka Tatarzy w stużbie Polsce 1918-2018 pod red. Barbary Pawlic-Miśkiewicz i Musy Çaxarxan Czachorowskiego (Białystok 1440/2018), jak również „Życie Tatarskie” i „Rocznik Tatarów Polskich" zawierają wiele danych dotyczących muzułmanów służących w PSZ, jednak pominięto tam niektóre związane $\mathrm{z}$ nimi postaci tego wyznania i nie zawsze podano prawdziwe informacje. Uznaję za stosowne opublikowanie niniejszego opracowania właśnie teraz, gdy w Polsce toczą się spory dotyczące przyjmowania imigrantów wyznania muzułmańskiego.

Chciałbym uzupełnić tę lukę. Interesują mnie postać imama Emira Bajraszewskiego, jedynego duchownego muzułmańskiego $\mathrm{w}$ PSZ ${ }^{18}$, jak również liczebność i cechy społeczne (narodowość, zawód, miejsce zamieszkania przed wojną itd.) żołnierzy pozostających pod jego opieką duszpasterską.

Za cezurę dolną przyjąłem 9 września 1939 roku, kiedy rząd polski na uchodźstwie pod kierownictwem gen. Felicjana Sławoja Składkowskiego zawarł umowę z rządem francuskim o utworzeniu Wojska Polskiego we Francji. Datę tę można uznać za początek PSZ. Narracja zakończy się na dacie 31 marca 1947 roku, kiedy rozwiązano wchodzące w jego skład Kierownictwo Marynarki Wojennej po uprzedniej demobilizacji jednostek lotnictwa i sił lądowych (wyjąwszy ostatni rozdział poświęcony dalszym losom bohaterów niniejszego opracowania) ${ }^{19}$.

9 Z. Werra, op. cit., s. 202-205, 210-211.

10 Adolf Fierla, [hasło w:] Encyklopedia katolicka, t. 5, Lublin 1989, kol. 175-176.

11 Andrzej Wantuła, [hasło w:] Wielka encyklopedia PWN, t. 28, Warszawa 2005, s. 547.

12 W. Anders, Bez ostatniego rozdziału. Wspomnienia z lat 1939-1946, Lublin 1995, s. 106-108.

13 N. Davies, op. cit., s. 262-263.

14 Z. Werra, op. cit., s. 203, 205, 219.

15 W. Anders, op. cit., s. 405, 438. Wbrew temu, co pisał generał, żaden muzułmanin nie spoczywa na cmentarzu polskich żołnierzy pod Monte Cassino.

${ }^{16}$ N. Davies, op. cit., s. 261, 266.

17 Z. Werra, op. cit., s. 203, 206.

18 Ppłk. dypl. Borkowski, meldunek nr L. dz. 728/GM/4 z 13 maja 1942 roku, PISM, A.XII.28/12, k. 38; „Komunikat (Z Urzędu Imama Wojskowego)” 1948, nr 1, s. 5, PISM, A.48.10.E; kmdr ppor. S. Gebethner, meldunek nr L. dz. 8658/R.OG./45 z 3 listopada 1945 roku, PISM, A.XII 28/13, k. 94; ks. A. Miodoński, meldunek nr L. dz. 378/45 z 8 listopada 1945 roku, ibidem, k. 88; płk dypl. Wiatr, Kapelani wyznań niekatolickich - meldunek, L. dz. 1252/V/42 z 22 marca 1942 roku, PISM, A.XII.28/12, k. 38; ppłk Zawadzki, Wykaz żołnierzy wyznań niekatolickich, L. dz. 9058/Ewid. I/45 z 21 listopada 1945 roku, PISM, A.XII 28/13, k. 93.

19 J. Romanowicz, Organizacja Polskiej Marynarki Wojennej we Francji i w Wielkiej Brytanii w latach 1939-1947, „Przegląd Historyczno-Wojskowy” 13 (64), 2012, nr 2 (240), s. 75-94, http://bazhum.muzhp.pl/ czasopismo/120/?idno=4477 (dostęp: 25.03.2019). 
W dalszej części artykułu będą się pojawiały wiadomości o przydziałach służbowych wymienianych osób. Wypada przeto zarysować strukturę organizacyjną PSZ. Ich Naczelnymi Wodzami byli kolejno: gen. Władysław Sikorski, gen. Kazimierz Sosnkowski, gen. Tadeusz Bór Komorowski (z powodu dostania się do niewoli niemieckiej 2 października 1944 roku jego obowiązki pełnił od lutego do czerwca 1945 roku gen. Władysław Anders). Po kapitulacji Francji 25 czerwca 1940 roku i ewakuacji części Wojska Polskiego we Francji do Wielkiej Brytanii składały się one z:

1. 1 Korpusu Polskiego (1 KP) formowanego w Szkocji od 1940 roku (dowódca: gen. Marian Kukiel);

2. Armii Polskiej na Wschodzie wyprowadzonej przez gen. Władysława Andersa z ZSRR przez Iran do mandatów i kolonii brytyjskich (Iraku, Transjordanii, Palestyny, Egiptu), do której włączono Samodzielną Brygadę Strzelców Karpackich, podzielonej w 1943 roku na 2 Korpus, który wysłano na front włoski, i Jednostki Wojskowe na Środkowym Wschodzie (dalej: JWŚW; niekiedy zwane 3 Korpusem Polskim), pozostałe w Egipcie i Palestynie (dowódca: gen. Michał Karaszewicz-Tokarzewski, de iure niezależny od gen. Andersa od 7 maja 1944 roku);

3. Polskich Sił Powietrznych, których pilotów po klęsce Francji w większości ewakuowano do Wielkiej Brytanii (kolejni dowódcy: gen. dyw. Józef Zając, maj 1940-18 lipca 1940 roku; gen. bryg. Władysław Jan Kalkus, 18 lipca 1940-19 września 1943 roku; gen. bryg. Stanisław Ujejski, wrzesień 1943-16 września 1947 roku, gen. bryg. M. Iżycki);

4. Marynarki Wojennej, której rekonstrukcję za granicą zapoczątkowało skierowanie do Wielkiej Brytanii 30 sierpnia 1939 roku niszczycieli „Grom”, „Błyskawica” i „Burza” (szef do września 1946 roku - wiceadm. Jerzy Świrski) ${ }^{20}$.

Jako źródła wykorzystane zostaną przede wszystkim: archiwalia zgromadzone w Instytucie Polskim i Muzeum imienia gen. Władysława Sikorskiego (Polish Institute and Sikorski Museum; dalej: PISM) w Londynie; redagowany od 1940 roku tamże „Dziennik Polski i Dziennik Żołnierza” (w latach 1940-1943 jako „Dziennik Polski”); przechowywana w bibliotece Polskiego Ośrodka Społeczno-Kulturalnego (dalej: POSK) w tym mieście „teka Jeżewskiego”; wspomnienia weteranów 2 KP - kpt. Eugeniusza Szymczaka, nagrane przez mnie w Londynie w maju 2018 roku, oraz por. Mustafy Abramowicza, wydane w formie książki i e-booka ${ }^{21}$, a także córki płk. Veli Bek Jedigara - Zulejhy Hanum Jedigar-Kalinovskiej22.

Podczas badań napotkałem, oprócz braku kompletnych informacji na temat danej osoby czy formacji wojskowej w źródłach, cztery trudności. Po pierwsze, wielu muzułmanów polskich nosiło polsko brzmiące nazwiska, na przykład Aleksandrowicz, Jakubowski, i popularne wśród chrześcijan imiona, jak Aleksander, Emilia. Po wtóre, zdarzały się przypadki

20 W. Biegański, Polskie Sity Zbrojne na Zachodzie 1939-1945, Warszawa 1990, s. 12-16, 42-43, 57-71; idem, Wojsko Polskie we Francji 1939-1940, Warszawa 1967, s. 226-240; Encyklopedia II wojny światowej, red. K. Sobczak et al., Warszawa 1975, s. 27-28, 121-122, 209, 285-287, 477-486, 494, 597, 610, 764.

${ }^{21}$ M. Abramowicz, Droga mojego życia. Ostatni ułan Rzeczpospolitej, Białystok 1438/2016. Dziękuję Fundacji z Brzezia Lanckorońskich i Polskiej Akademii Umiejętności za przyznanie mi stypendium umożliwiającego kwerendę archiwalną i biblioteczną w Londynie w maju 2018 roku.

${ }^{22}$ Z.H. Jedigar-Kalinovska, Veli Bek Jedigar, http://www.polonia-baku.org/pl/losy.phtml\#jedigar (dostęp: 3.03.2019). 
konwersji polskich Tatarów na chrystianizm (zwykle rzymski katolicyzm, rzadziej prawosławie czy protestantyzm) ${ }^{23}$, na przykład rzymskim katolikiem był żołnierz 2 KP tatarskiego pochodzenia płk Leon Hózman-Mirza-Sulkiewicz ${ }^{24}$, a prawdopodobnie również inny polski Tatar, Jakub Jakubowski, na którego grobie ustawiono krzyż ${ }^{25}$. Rozpoznaję tedy wyznawców islamu w PSZ po zdjęciach nagrobków z symbolem tej religii - półksiężycem, na podstawie informacji o wyznawanej przez nich religii zamieszczanych w prasie, urzędowych rejestrach i opracowaniach, jak również po imionach pochodzących z języka arabskiego albo różnych narzeczy tureckich, niespotykanych wśród ludności chrześcijańskiej (na przykład Abu-Bekir, Hamid). Po trzecie, jak wspominali urzędnicy Wydziału Politycznego MON, przedstawiciele mniejszości wyznaniowych, „aby nie narazić się na ewentualne przykrości", podawali się za rzymskich katolików albo bezwyznaniowych (obawy te okazywały się często przesadzone ${ }^{26}$. Po czwarte, różnie zapisywano, a niekiedy przestawiano i mylono w źródłach oraz opracowaniach nazwiska i imiona zarówno egzotycznego pochodzenia, jak i polskie, a także podawano błędne daty urodzenia bohaterów niniejszego tekstu, co budziło wątpliwości, czy chodzi o tę samą osobę i jak się ona rzeczywiście nazywała. Przykładowo w Słowniku biograficznym Tatarów polskich wymieniono jako pochowanego na polskim cmentarzu wojskowym w Loreto niejakiego Ibrahima Radkiewicza, chociaż jedyną spoczywającą tam osobą tej narodowości jest Sulejman Rodkiewicz.

\section{Statystyki i przydział służbowy muzułmanów w ramach PSZ}

W 2 KP służyło na dzień 1 października 1944 roku 16 żołnierzy-muzułmanów, w tym 5 kaprali, 4 starszych strzelców (na froncie), 1 kapitan (w Bazie). Wedle danych z 1 maja 1944 roku liczył on 2978 oficerów i 43021 podoficerów i szeregowców ${ }^{27}$. Liczba wyznawców islamu w 2 KP (bez JWŚW) w ciągu roku wzrosła do 36 żołnierzy, w tym: 6 oficerów, 7 podoficerów, 17 szeregowców i 6 ochotniczek. Jego stan rzeczywisty wynosił we wrześniu 1945 roku 95079 osób ${ }^{28}$. Napływali do niego nie tylko muzułmanie wzięci do niewoli czy deportowani przez Sowietów, lecz również uciekający w różnych momentach wojny ze strefy okupowanej przez Niemców (na przykład por. Dżennet Dżabagi

23 A. Miśkiewicz, Tatarzy polscy 1918-1939, Warszawa 1990, s. 24.

24 „Dziennik Polski i Dziennik Żołnierza” 1958, nr 105, s. 4; nr 111, s. 4; nr 114, s. 4; 1959, nr 102, s. 4; Słownik biograficzny Tatarów Polskich, red. A. Miśkiewicz, Białystok 1438/20196, s. 167-168; Tatarzy w stużbie Polsce 1918-2018, red. B. Pawlik-Miśkiewicz, M. Çaxarxan Czachnowski, Białystok 1440/2018, s. 199. W przywołanych opracowaniach podano błędną datę jego śmierci - 1960 zamiast 1 maja 1958 roku.

${ }^{25}$ Jakub Jakubowski, http://www.polskicmentarzbolonia.pl/pl/lista-pochowanych-bolonia/cart/1456/ jakub-jakubowski.html (dostęp: 19.02.2019); Słownik biograficzny Tatarów..., s. 738; Tatarzy w służbie Polsce..., s. 36, 78 .

${ }^{26}$ Notatka w Sprawach Wyznaniowych $w$ Polskich Siłach Zbrojnych [pisownia oryginalna - P.B.], MON. Wydział Polityczny — Referat Wyznań, PISM, A.XII.28/13, k. 35.

27 Encyklopedia II wojny..., s. 122.

28 Miesięczny raport stanu za miesiąc wrzesień 1945 roku z dnia 30 września 1945 roku. Zestawienie ogólne. L. dz. 9259/tjn./45, PISM, A XI 29/25; Zestawienie ogólne żołnierzy wyznań niekatolickich w 2. Korpusie i Bazie w/d stanu z dnia 1 października 1944 roku, PISM A.XII 28/13, k. 6. 
Skibniewska, płk Veli Bek Jedigar, dr Stefan Murza-Murzicz) ${ }^{29}$. Dane osobowe żołnierzy $2 \mathrm{KP}$ wyznania mahometańskiego, które udało mi się ustalić, podaję w poniższej tabeli (podaję ostatni stopień wojskowy, jaki uzyskali za życia) ${ }^{30}$.

Tabela 1. Muzułmanie w 2 KP

\begin{tabular}{|c|c|c|c|}
\hline Imię i nazwisko & Stopień & Przydział służbowy & $\begin{array}{c}\text { Data } \\
\text { i miejsce urodzenia }\end{array}$ \\
\hline $\begin{array}{l}\text { Mustafa Stefan Abramo- } \\
\text { wicz }\end{array}$ & por. & $\begin{array}{l}1 \text { Pułk Ułanów } \\
\text { Krechowieckich }\end{array}$ & 20.10.1915, Kleck \\
\hline Abraham Aleksandrowicz & st. ułan & $\begin{array}{l}1 \text { Pułk Ułanów } \\
\text { Krechowieckich }\end{array}$ & 1902 \\
\hline Emir Bajraszewski & płk dypl. & imam & 21.04.1914, Nowogródek \\
\hline $\begin{array}{l}\text { Abdul Hamid Churamo- } \\
\text { wicz }\end{array}$ & ppłk & Polska YMCA (Baza?) & 21.08.1892, Łuck \\
\hline Aleksander Giembicki & ułan & $\begin{array}{l}1 \text { Pułk Ułanów } \\
\text { Krechowieckich }\end{array}$ & 1916 \\
\hline Abu Bekir Jakubowski & ppor. & $\begin{array}{l}8 \text { Dywizja Piechoty } \\
\text { (26.02.-5.05.1942), } \\
7 \text { Dywizja Piechoty } \\
\text { (5.05.1942-1.10. 1943), } \\
4 \text { Pułk Pancerny } \\
(1.10 .1943-1946)\end{array}$ & 25.08.1922, Wilno \\
\hline Veli Bek Jedigar & płk dypl. & nieznany & $\begin{array}{l}\text { 31.10.1898, Takiało } \\
\text { k. Baku }\end{array}$ \\
\hline Adil Bek Kułatti & strzelec & nieznany & $\begin{array}{l}\text { 18.08.1905, Narcana } \\
\text { (Kaukaz) }\end{array}$ \\
\hline Majram Bek Margoti & por. & nieznany & nieznane \\
\hline Mahmet Mucharski & kpt. & Baza & 28.02 .1909 \\
\hline dr Helena Murza-Murzicz & ochotniczka & Pomocnicza Służba Kobiet & 2.09.1905, Pińsk \\
\hline Stefan Półturzycki & ułan & $\begin{array}{l}1 \text { Pułk Ułanów } \\
\text { Krechowieckich }\end{array}$ & 1905 \\
\hline Sulejman Rodkiewcz & ułan & $\begin{array}{l}12 \text { Pułk Ułanów } \\
\text { Podolskich }\end{array}$ & 16.07.1923, Nowogródek \\
\hline
\end{tabular}

29 T. Zaniewska, Dżennet znaczy raj, Białystok 2002, s. 79-124; Z.H. Jedigar-Kalinovska, op. cit.; PISM, kol. 394/14, k. 49.

${ }^{30}$ Nie udało mi się znaleźć żadnych źródeł potwierdzających istnienie Polsanowicza, Tatara z okolic Nowej Wilejki, który miał służyć w 2 KP, wspominanego przez Henryka Panasa (zob. idem, Jak mi było u Andersa, Warszawa 1988, s. 161). Nie wymieniam tutaj również Zofii Romanowicz pracującej wedle danych, które posiadam, w Polskim Czerwonym Krzyżu w Rzymie, a więc poza 2 KP (zob. „Dziennik Polski i Dziennik Żołnierza” 1981, nr 260, s. 4). 


\begin{tabular}{l|l|l|l}
\hline $\begin{array}{l}\text { Dżennet Dżabagi-Skib- } \\
\text { niewska }\end{array}$ & por. & $\begin{array}{l}\text { Pomocnicza Służba Kobiet } \\
\text { (2 Brygada Wileńska } \\
\text { 3 Dywizji Strzelców } \\
\text { Karpackich) }\end{array}$ & 08.04.1915, Petersburg \\
\hline Emilia Szehidewicz & nieznany & Pomocnicza Służba Kobiet & nieznane \\
\hline Fuad Szehidewicz & ppłk & $\begin{array}{l}\text { 1 Pułk Ułanów } \\
\text { Krechowieckich }\end{array}$ & 15.01 .1920$, Słonim \\
\hline Jakub Szehidewicz & ppor. & $\begin{array}{l}\text { 23 Pułk Piechoty 7 Dywizji } \\
\text { Piechoty }\end{array}$ & 1893, Słonim \\
\hline Jan Szahidewicz & kapral pchor. & $\begin{array}{l}\text { 15 Pułk Kawalerii } \\
\text { (8.10.1942-31.12.1944), } \\
\text { 25 Pułk Ułanów Wielko- } \\
\text { polskich (31.12.1944-1946) }\end{array}$ & 12.12 .1925$, Nowogródek \\
\hline Umasz Jusow & kezerwy & nieznany & nieznane \\
\hline
\end{tabular}

Źródła: „Dziennik Polski i Dziennik Żołnierza” 1955, nr 308, s. 4; 1972, nr 7, s. 4; PISM, A.XII.86/26, k. 43, k. 108; kol. 334/9; kol. 394/14, k. 48; kol. 520/17; kol. 554/III/70; kol. 554/IV/5; kol. 554/IV/6; kol. 554/IV/7a; Z.H. Jedigar-Kalinovska, op. cit..; Stownik biograficzny Tatarów..., s. 45, 62-64, 118-119, 177-181; Tatarzy w stużbie Polsce..., s. 22, 27-29, 52, 60, 72, 122, 123; „Tydzień Polski” 2004, nr 36, s. 23; T. Zaniewska, op. cit., passim.

W JWŚW po wyodrębnieniu 2 KP pozostawiono (albo przydzielono do nich później) kilku muzułmanów, których personalia ujawniam w poniższej tabeli.

Tabela 2. Muzułmanie w JWŚW

\begin{tabular}{l|l|l|l}
\hline \multicolumn{1}{c|}{ Imię i nazwisko } & \multicolumn{1}{c|}{ Stopień } & Przydział służbowy & \multicolumn{1}{c}{$\begin{array}{c}\text { Data } \\
\text { i miejsce urodzenia }\end{array}$} \\
\hline $\begin{array}{l}\text { Bahaeddin (Bahaedin, } \\
\text { Bahajedin) Emir Hasan } \\
\begin{array}{l}\text { Chursz (Churszyłow, } \\
\text { Hursz) }\end{array}\end{array}$ & $\begin{array}{l}\text { płk dypl. } \\
\text { kaw. }\end{array}$ & $\begin{array}{l}\text { Ośrodek Rezerwy Per- } \\
\text { sonalnej Oficerów } \\
\text { JWŚw }\end{array}$ & $\begin{array}{l}\text { 28.05.1894, Gunib, } \\
\text { Kaukaz }\end{array}$ \\
\hline $\begin{array}{l}\text { Hamid Korchmaz (Korh- } \\
\text { maz) }\end{array}$ & por. & nieznany & nieznane \\
\hline Husein Kumuz & mjr & sztab & 1891, Elburgan (Kaukaz) \\
\hline Roman Smajkiewicz & nieznany & sztab & 12.04 .1892$, Kleck \\
\hline
\end{tabular}

Źródła: P. Adamczewski, Listy dotyczace osób pochodzenia kaukaskiego służacych w Wojsku Polskim i działaczy ruchu prometejskiego, przechowywane w polskich archiwach w Londynie, http://dx.doi.org/10.12775/SDR.2015.2.08 (dostęp: 10.02.2018); PISM, A.XII.27/67; kol. 320/17, k. 82; 320/29; R. Berger, Z listów do Macieja (Musy) Konopackiego, „Rocznik Tatarów Polskich. Czasopismo naukowe i literacko-społeczne poświęcone historii, kulturze oraz teraźniejszości Tatarów w Polsce i Europie Środkowo-Wschodniej" 2 (16), 2015 (1436/37), s. 245-249, http://bibliotekatatarska.pl/rocznik-tatarow-polskich/ (dostęp: 27.11.2019); W. Romanow-Głowacki, Mjr. Huseyin Kumuz, „Dziennik Polski i Dziennik Żołnierza" 1965 , nr 3, s. 4.

Udało się ustalić, że do innych jednostek wchodzących w skład PSZ na Zachodzie przydzielono przynajmniej trzech wyznawców islamu. W Samodzielnej Brygadzie Strzelców Podhalańskich, wchodzącej w skład Wojska Polskiego we Francji, służył płk 
Ibrahim Joachim Bajraszewski (1912-1996), polski Tatar. Brał udział w bitwie pod Narwikiem. W 1940 roku zostaje odznaczony Krzyżem za Męstwo i Virtuti Militari. Po rozbiciu jego jednostki przez Niemców w Bretanii i kapitulacji Francji w czerwcu 1940 roku przyłączył się do tamtejszego ruchu oporu. Aresztowany przez Gestapo w 1943 roku, przebywał do kwietnia 1945 roku w niemieckim obozie koncentracyjnym Buchenwald ${ }^{31}$. W Polskich Siłach Powietrznych jako pilota zatrudniono jego współwyznawców - kpr. Samuela Bajraszewskiego i st. sierż. Amurat Gembickiego, również polskich Tatarów ${ }^{32}$.

\section{Cechy społeczne muzułmanów służących w PSZ}

Większość muzułmanów w PSZ na Zachodzie stanowili Tatarzy polscy zamieszkujący przed 1939 rokiem województwa wileńskie i nowogródzkie (w tym imam). Zdarzali się tam jednak przedstawiciele innych nacji, jak pochodzący z Dagestanu Awar płk Bahajedin Chursz, Azerbejdżanin płk Veli Bek Jedigar, Czerkies mjr Husein Kumuz, córka Ingusza i polskiej Tatarki por. Dżennet Dżabagi-Skibniewska czy członkowie bliżej nieznanych mi ludów zamieszkujących Kaukaz: Adel Bek Kułatti, Majram Bek Margoti, por. Hamid Korchmaz, kpt. Umasz Jusow ${ }^{33}$.

Nie dysponuję pełnymi danymi na temat wykształcenia i zawodu muzułmanów wcielonych do PSZ. Na podstawie wspomnień kpt. Eugeniusza Szymczaka i kpt. Mustafy Abramowicza $^{34}$, książki dr. Alego Miśkiewicza ${ }^{35}$ i zachowanych archiwaliów ${ }^{36}$ można przypuszczać, że większość z nich pracowała w rolnictwie i miała wykształcenie niepełne podstawowe. „Dużo było na wsi, rolnicy” - wspominał kpt. Eugeniusz Szymczak. Zdarzali się jednak wśród nich rzemieślnicy (S. Półturzycki), prawnicy (A.H. Churamowicz),

31 M. Borkowski, Tatar $i$ Viking w jednym stali domu, „Polska Zbrojna” 1992, nr 110 (412), dodatek „Magazyn Tygodniowy” nr 23 (86), s. I; Tatarzy w stużbie Polsce..., s. 28, 61; B. Bratbak, Tatar walczacy o Narvik, przel. E. Hygen, PISM A XII 85/130/171, k. 1-10 (mps).

32 S. Hordejuk, Mahomet Obuchowski (1898-1934). Wspomnienie w 80. rocznicę śmierci, „Życie Tatarskie” 2014, nr 40 (117), s. 85-93; A. Krzystek, T.J. Krzystek, Polskie Sity Powietrzne Wielkiej Brytanii w latach 19401947 łącznie z Pomocnicza Lotnicza Stużba Kobiet (PLSK-WAAF), Sandomierz 2012, s. 75, 192; Lotnicy. Samuel Bajraszewski, https://niebieskaeskadra.pl/?control=8\# (dostęp: 9.02.2019) (widoczne zdjęcie grobu); Tatarzy w służbie Polsce..., s. 37. Samuel Bajraszewski, ur. 20 września 1926 roku w Słonimiu, w 1948 roku powrócił do kraju; zm. 6 lipca 1956 roku w Gdańsku, pochowany na mizarze w Kruszynianach. Kpr. Amurat Gembicki, ur. 24 listopada 1926 roku w Kątach, radiooperator w 307. Dywizjonie Myśliwskim Nocnym; po drugiej wojnie światowej mieszkał i pracował w Londynie jako kelner, dalsze losy nieznane.

33 Kaukaz zamieszkiwały, przed włączeniem tego obszaru do Rosji w XIX wieku i masowym napływem tam osadników wschodniosłowiańskich, narody i plemiona różnego pochodzenia: irańskiego (Osetyjczycy), tureckiego (między innymi Awarowie, Azerbejdżanie, Kumycy), Ormianie, mówiący językiem z grupy indoeuropejskich, ale także wiele ludów praindoeuropejskich, a zarazem nietureckich, zwanych kaukaskimi (Abchazi, Gruzini, Czerkiesi, Czeczeni, Ingusze). W źródłach polskich z lat czterdziestych XX wieku często określa się je mianem „górali kaukaskich”. Ja skrótowo nazywam je „Kaukazczykami”, „pochodzącymi z Kaukazu” lub „zamieszkującymi Kaukaz”.

34 M. Abramowicz, op. cit., s. 24.

35 A. Miśkiewicz, op. cit., s. 66, 109.

36 Ewidencja ułanów i podoficerów - 1941/42, PISM, kol. 554/IV/6. 
ekonomiści (I. Bajraszewski), zawodowi wojskowi (E. Bajraszewski, J. Szechidewicz), studenci (A.B. Jakubowski) i osoby bez zawodu (J. Szehidewicz). Prawdopodobnie wszyscy wymienieni wyznawcy islamu pochodzący z Kaukazu byli przed wybuchem wojny etatowymi żołnierzami Wojska Polskiego i mieli wykształcenie średnie bądź wyższe ${ }^{37}$. W 2 KP pracowało trzech lekarzy wyznania muzułmańskiego, Tatarów polskich, absolwentów Uniwersytetu Stefana Batorego w Wilnie: dr Helena Murza-Murzicz (internista), dr Stefan Murza-Murzicz (internista) i kpt. dr Leon Achmatowicz (chirurg) ${ }^{38}$.

Przynajmniej jeden żołnierz PSZ wyznający islam poległ, a mianowicie ułan Sulejman Rodkiewicz ${ }^{39}$, dwóch innych zmarło wskutek odniesionych w walkach ran: strzelec Adil Bek Kułatti ${ }^{40}$ i płk Bahaedin Chursz ${ }^{41}$.

\section{Powody wstępowania muzułmanów do PSZ}

Muzułmanie zaciągali się do PSZ, mając do wyboru wojska francuskie, brytyjskie, radzieckie czy kolaborację z Niemcami, z pięciu powodów.

Po pierwsze, wielu z nich było polskimi Tatarami żyjącymi od kilku wieków na obszarze Wielkiego Księstwa Litewskiego. Niektóre rodziny tatarskie zostały tam sprowadzone jeszcze przez jego władców w XIV wieku ze Złotej Ordy do walki z Krzyżakami i Wielkim Księstwem Moskiewskim. Przez ten czas uległy one daleko posuniętej polonizacji, rzadziej lituanizacji, albarutenizacji (przez którą rozumiem przyjęcie białoruskiej świadomości narodowej) czy rusyfikacji. Sprzyjały temu unie z Polską w Krewie (1386 rok), Horodle (1413 rok) i Lublinie (1569 rok) oraz mieszane małżeństwa z chrześcijankami (prawnie zakazane w 1616 roku). Chociaż większość z nich pozostała przy sunnickiej wersji islamu (na co zezwalały im przywileje książęce i królewskie), pod wpływem

37 L. Bohdanowicz, Polska i Rosja a świat muzułmański, Londyn 1949, s. 17; R. Buliński, Rodzina Dżabagi - tułaczy los emigrantów kaukaskich, http://www.jpilsudski.org/component/k2/item/2441-rodzinadzabagi-tulaczy-los-emigrantow-kaukaskich (dostęp: 25.03.2019); Z.H. Jedigar-Kalinovska, op. cit.; Emir Hassan Chursz Bahaedin. Lista rewizyjna, Komenda Ośrodka Rezerwy Personalnej Oficerów JWSW, PISM, A.XII.27/67; Słownik biograficzny Tatarów..., s. 62-63; T. Zaniewska, op. cit., passim. V.B. Jedigar był absolwentem Wyższej Szkoły Wojennej w Warszawie. B.E. Chursz miał wykształcenie średnie. D. Dżabagi-Skibniewska ukończyła Wyższa Szkołę Wschodoznawczą przy Instytucie Wschodnim w Warszawie.

38 „Dziennik Polski i Dziennik Żołnierza” 1977, nr 47, s. 4; 1978, nr 138, s. 4; Leon Achmatowicz. Deklaracja, Związek Lekarzy Polskich w Imperium Brytyjskim, PISM, kol. 394/14, k. 1; Helena Murza-Murzicz. Deklaracja, Związek Lekarzy Polskich w Imperium Brytyjskim, ibidem, k. 48; Stefan Murza-Murzicz. Deklaracja, Związek Lekarzy Polskich w Imperium Brytyjskim, ibidem, k. 49; Spis imienny lekarzy w/g specjalności, PISM, kol. 394/1; ibidem, kol. 334/9. Dr S. Murza-Murzicz formalnie został zatrudniony przez PCK, niemniej pracował dla $2 \mathrm{KP}$ w obozie w Cassercie.

39 B. Jackiewicz et al., Loreto: il cimitero militare polacco, Falconara M.ma (An) 2007, s. 154, 174; Przewodnik po polskich cmentarzach wojennych we Włoszech. Monte Cassino, Loreto, Loreto, Casamassima, oprac. o. A. Struziński OP, Warszawa 1994, s. 85; Sulejman Rodkiewicz, http://polskiecmentarzewewloszech. eu/pl/ lista-pochowanych-loreto/cart/3658/sulejman-rodkiewicz.html (dostęp: 21.03.2019).

40 Adil Bek Kułatti, https://polskiecmentarzewewloszech.eu/pl/lista-pochowanych-casamassima/cart/ 2667/adil-bek-kulatti.html (dostęp: 25.03.2019); N. Davies, op. cit., s. 260.

${ }^{41}$ Emir Hassan Chursz Bahaedin... 


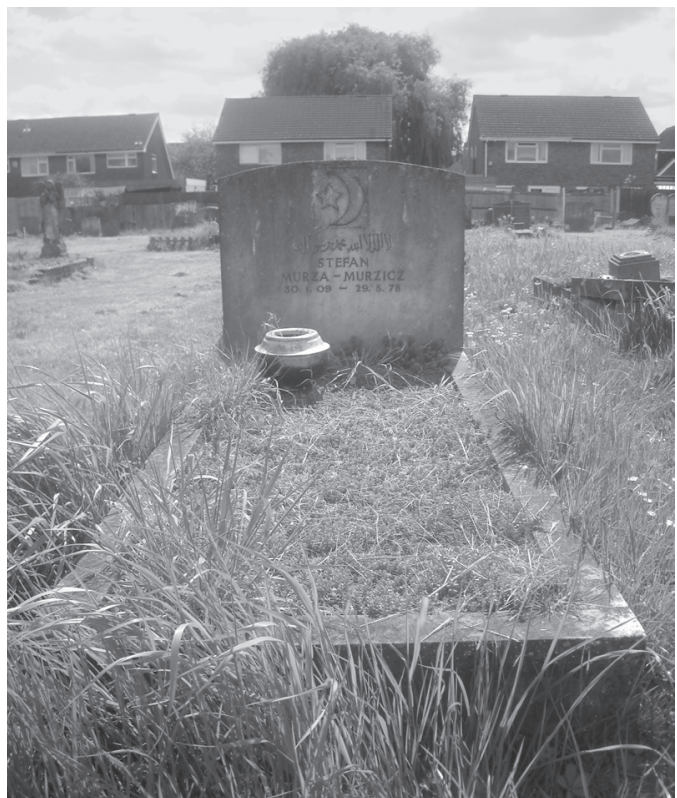

Rycina 1. Grób dr Stefana Murzy-Murzicza, Londyn, Streatham Park Cementery. Fot. Piotr Bukowczyk

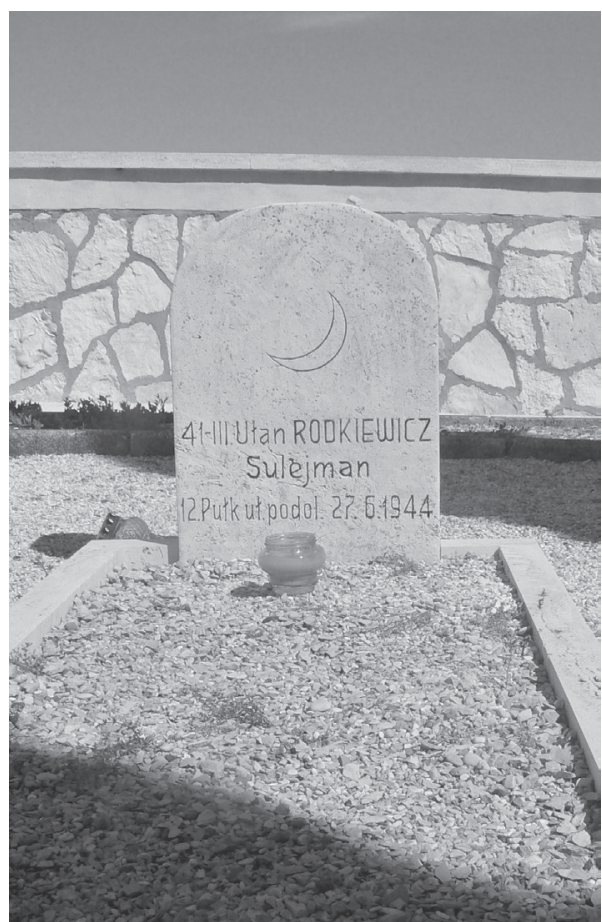

Rycina 2. Mogiła ułana Sulejmana Rodkiewicza na polskim cmentarzu wojskowym w Loreto. Fot. Aleksander Rutkiewicz 
chrześcijańskiego otoczenia, tudzież własnych dawnych wierzeń zrezygnowali na przykład z dozwolonej przez Koran poligamii, wbrew przepisom własnej religii pili alkohol i modlili się tylko dwa razy dziennie, jedli i pili za dnia w Ramadanie, kobiety tatarskie nie zasłaniały twarzy i nie nosiły nakryć głowy, stroili choinki w okresie Świąt Bożego Narodzenia i malowali pisanki na Wielkanoc (chociaż islam odrzuca istnienie Trójcy Świętej, Wcielenie Boga czy śmierć Jezusa na krzyżu za grzechy ludzi), a także zajmowali się czarami (co wielu teologów muzułmańskich traktuje jako apostazję, za którą Koran przewiduje karę śmierci). Wielu z nich słabo zresztą znało dogmaty i zasady moralne swojej religii ze względu na brak medres (muzułmańskich wyższych szkół teologiczno-prawnych), zarówno na obszarze Złotej Ordy, jak i Wielkiego Księstwa Litewskiego (chociaż działały tam szkoły koraniczne przy meczetach ${ }^{42}$. Polscy Tatarzy-muzułmanie angażowali się w działalność na rzecz odzyskania albo zachowania przez Polskę niepodległości, na przykład gen. Józef Bielak brał udział w powstaniu kościuszkowskim ${ }^{43}$, Aleksander Sulkiewicz walczył w Legionach Polskich ${ }^{44}$, gen. Aleksander Romanowicz zaś w Wojsku Polskim w czasie wojny polsko-bolszewickiej ${ }^{45}$.

Po wtóre, zarówno oni, jak i mahometanie pochodzący z Kaukazu żywili niechęć wobec Rosji i Rosjan, których oskarżali o faworyzowanie prawosławnych kosztem muzułmanów i wynaradawianie oraz wyniszczanie ludów tureckich, a także kaukaskich w przeważającej części wyznających islam ${ }^{46}$.

Po trzecie, negatywnie oceniali komunizm sowiecki i wynikające z niego: masowy terror, powszechną inwigilację obywateli przez służby specjalne, kłamliwą propagandę, zniewolenie przez rząd, nędzę i ateizację społeczeństwa ${ }^{47}$.

42 M. Abramowicz, op. cit., s. 22, 97-98, 105, 108, 113, 116, 120; J. Bielawski et al., Religie uniwersalistyczne. Zarys dziejów, Warszawa 1982, s. 389-392, 420; L. Bohdanowicz, The muslims in Poland. Their origin, history, and cultural life, „Journal of the Royal Asiatic Society” October 1942, s. 163-180; S. Chazbijewicz, Tatarzy, [hasło w:] Encyklopedia katolicka, t. 19, Lublin 2014, kol. 548-549; Koran, przeł. J. Bielawski, Warszawa 1986, 2:219, 5:90-91 (alkohol); 3:3, 4:3 (wielożeństwo); 24:31, 7:27, 33:59 (zakrywanie głowy tudzież twarzy przez kobiety); 2:183,185 (Ramadan); 11:114, 17:78; 73:20 (modlitwa), 4:88-89, 16:106 (kara śmierci za apostazję); A. Miśkiewicz, op. cit., s. 97-98, 131, 150-151; Sunna (Hadisy), przeł. J. Danecki, Imam Mahmud Taha Żuk, [w:] Religie Wschodu i Zachodu. Wybór tekstów źródłowych, red. K. Banek, Warszawa 1991, s. 348-351; J. Tyszkiewicz, Tatarzy w Polsce i Europie. Fragmenty dziejów, Pułtusk 2009, s. 15, 152, 153, 154, 157-158, 198-199, 207; A. Wąs SVD, Apostazja w islamie, https://religie.wiara.pl/doc/496521.Apostazja-w-islamie (dostęp: 4.03.2019); idem, Zakaz spożywania alkoholu, https://religie.wiara.pl/doc/497096.Zakaz-spozywania-alkoholu\# (dostęp: 8.02.2019).

${ }^{43}$ Bielak Józef, https://encyklopedia.pwn.pl/haslo/Bielak-Jozef;3877363.htm (dostęp: 8.02.2019); J. Tyszkiewicz, Z historii Tatarów polskich 1794-1944, Pułtusk 2002, s. 33-47.

44 Sulkiewicz Aleksander, https://encyklopedia.pwn.pl/haslo/Sulkiewicz-Aleksander;3981243.html (dostęp: 8.02.2019).

45 Tatarzy w służbie Polsce..., s. 116.

46 E. Bajraszewski, Wolna trybuna! Odpowiedzi na głosy czytelników. Muslimowi w Dżałał-Abad, „Komunikat (Z Urzędu Imama Wojskowego)” 1948, nr 2, s. 6, PISM A.48.10.E; L. Bohdanowicz, Polska i Rosja..., s. $15-24$.

47 M. Abramowicz, op. cit., s. 66, 72, 77-78, 80, 82-89, 93; E. Bajraszewski, op. cit.; idem, Co to jest islam, 1-sza (Pogadanka religijna), „Komunikat (Z Urzędu Imama Wojskowego)” 1948, nr 2, s. 2. 
Strategią bojową Rosji był atak — pisał por. Mustafa Abramowicz - polegający na ruszeniu na nieprzyjaciela jak największą ilością żołnierzy, a nie na użyciu dobrego sprzętu bojowego. Nie liczono się z życiem ludzkim, ważne było zwycięstwo za wszelką cenę. [...] Dlatego dzisiaj dziękujemy Bogu i naszemu dowódcy, gen. Andersowi, za to, że mogliśmy opuścić tę przeklętą dla nas ziemię Związku Radzieckiego ${ }^{48}$.

Wypada dodać, że po 17 września 1939 roku przeważająca część polskich muzułmanów znalazła się na terenach okupowanych przez ZSRR. Na obszarach zajętych przez Niemcy przed 22 czerwca 1941 roku tylko w Warszawie istniała gmina mahometańska ${ }^{49}$.

Po czwarte, gen. Władysław Anders, sam pochodzący ze spolszczonej rodziny niemieckiej wyznania ewangelicko-augsburskiego (konwertował na rzymski katolicyzm w 1942 roku $)^{50}$, chętnie przyjmował do dowodzonych przez siebie formacji wojskowych przedstawicieli mniejszości religijnych i etnicznych. „Stałem na stanowisku - pisał — że skoro tworzymy dalszy ciąg Armii Polskiej, wszyscy obywatele - bez różnicy wyznania i narodowości - mogą się w niej pomieścić" 51 . Podobnie myśleli kolejni premierzy rządu emigracyjnego w latach 1939-1945 - gen. Władysław Sikorski oraz jego następcy wywodzący się ze Stronnictwa Ludowego (SL) i Polskiej Partii Socjalistycznej (PPS) - Stanisław Mikołajczyk i Tomasz Arciszewski. Gen. Władysław Sikorski na pytanie Stalina „Co wam po Białorusinach, Ukraińcach i Żydach? Wam potrzebni Polacy, to najlepsi żołnierze”, odpowiedział: „Nie myślę o ludziach, tych można wymienić na Polaków obywateli sowieckich, ale nie mogłem z punktu widzenia zasadniczego przyjąć sugestii o płynności granic Rzeczpospolitej. Ci, co w r. 1939 byli obywatelami polskimi, obywatelami polskimi pozostali”52. „Wszystkim obywatelom państwa - stwierdzono w programie SL z 1935 r. - bez względu na ich narodowość i wyznanie — zapewniona ma być równość praw" 53 . W programie PPS z 1937 roku można zaś przeczytać:

Polska Partia Socjalistyczna uznaje wolność sumienia za jedno z najbardziej podstawowych praw obywatela w państwie [...]. Rozwiązanie zaś sprawy narodowościowej w granicach jednego państwa jest wykonalne i dziś przez konsekwentne wprowadzenie w życie: a) zupełnego równouprawnienia wszystkich obywateli państwa bez różnicy narodowości i wyznania; [...] c) autonomii narodowo-kulturalnej dla mniejszości rozsianych po całym państwie ${ }^{54}$.

Po piąte, cały czas wśród wychodźstwa polskiego były żywe promowane przez Józefa Piłsudskiego idee prometejskie, które przewidywały wykorzystanie dążeń niepodległościowych ludów kaukaskich do osłabienia i rozbicia ZSRR. Leon Bohdanowicz, w czasie drugiej wojny światowej pracownik Ministerstwa Informacji i Propagandy, a po jej zakończeniu działacz Gminy Muzułmanów Polskich, a także wykładowca Instytutu Bliskiego i Środkowego Wschodu „Reduta” w Londynie pisał:

48 M. Abramowicz, op. cit., 144.

49 A. Miśkiewicz, op. cit., s. 63, 81.

50 K. Szmagier, Generał Anders i jego żołnierze, Warszawa-Łódź 1993, s. 9, 18, 105-106.

51 W. Anders, op. cit., s. 106.

52 Cyt. za: O. Terlecki, Generał Sikorski, t. 1, Kraków 1981, s. 424-425.

53 Program Stronnictwa Ludowego 8 grudnia 1935 r., [w:] J. Juchnowski, W. Kalicki, J. Tomaszewski, Polska myśl polityczna XX wieku. Wybór tekstów źródłowych z komentarzem, t. 1. Od końca XIX wieku do 1939 r., Legnica 2003, s. 180.

54 Program Polskiej Partii Socjalistycznej uchwalony na XXIV Kongresie w Radomiu dnia 2 lutego 1937 r., [w:] J. Juchnowski, W. Kalicki, J. Tomaszewski, op. cit., s. 220. 
Aczkolwiek Polska nie ma w tej chwili wspólnej granicy z krajami muzułmańskimi łatwo przekonać się patrząc na mapę, że ów zespół narodów muzułmańskich, a szczególnie graniczące z Rosją państwa muzułmańskie są obecnie jej najbardziej naturalnym sojusznikiem w walce przeciw Rosji ${ }^{55}$.

\section{Stosunki między muzułmanami a żołnierzami innych wyznań w ramach PSZ}

„My nie mieliśmy nigdy żadnych kłopotów. Byliśmy wiernymi braćmi, żołnierzami. Tak, że ja osobiście nie mogę narzekać - wspominał w rozmowie ze mną kpt. Eugeniusz Szymczak. [...] Czy muzułmanie, czy tam prawosławni, czy Żydzi, ja nie moge powiedzieć, to byli wszyscy koledzy”. Na moje pytanie: „Czy były konflikty między duchownymi?”, odparł: „Nie. Ja tego nie pamiętam”. Piotr Medyna, służący w Samodzielnej Brygadzie Strzelców Karpackich, twierdził jednak, że

dla przyzwyczajonych do naprawdę demokratycznego stosunku oficerów do szeregowych w Brygadzie, wydawało się co najmniej dziwne, że w niektórych jednostkach przybyłych z ZSRR zdarzają się wypadki stosowania bezdusznych kar dyscyplinarnych, nadużywania władzy wobec podwładnych i nietolerancji szczególnie w stosunku do mniejszości narodowych ${ }^{56}$.

Jednak były one, jego zdaniem, rzadkie. Jak wspominał:

W parę dni po masowej dezercji żołnierzy-Żydów znaleźliśmy notatki w prasie miejscowej, że sprawa była poruszana w Brytyjskiej Izbie Gmin i Kongresie USA, przy czym interpelujący posłowie i kongresmeni uzasadniali ucieczkę Żydów ich prześladowaniem w wojsku polskim. [...] Mimo nie zawsze właściwego stosunku kadry oficerskiej i podoficerskiej do żołnierzy, o czym pisałem poprzednio, nie mogliśmy ustalić faktów, które by nieprzychylne dla Polaków wystąpienia w parlamentach angielskim i amerykańskim usprawiedliwiały ${ }^{57}$.

Wydaje się, że uwagę tę można rozciągnąć także na inne mniejszości narodowe i wyznaniowe w PSZ.

\section{Losy muzułmanów służących w PSZ po ich rozwiązaniu}

Losy Abrahama Aleksandrowicza, Aleksandra Giembickiego, Stefana Półturzyckiego, Romana Smajkiewicza, Emilii Szehidewicz po likwidacji PSZ pozostają nieznane.

Mustafa Abramowicz osiadł w Wielkiej Brytanii. Tam pracował fizycznie i ożenił się Haliną Milkamanowicz, polską Tatarką, z którą miał córki Mary i Janet. Awansowany był 21 grudnia 1944 roku na starszego ułana, w 2000 roku na podporucznika, a w 2016 roku na porucznika. Odznaczono go Krzyżem Kawalerskim Orderu Odrodzenia Polski, Krzyżem za Kampanię Wrześniową, Medalem Wojska, Krzyżem Pamiątkowym Monte Cassino oraz medalami brytyjskimi: 1939-1945 Star (Gwiazda za Wojnę 1939-1945),

55 L. Bohdanowicz, Polska i Rosja..., s. 25.

56 P. Medyna, Do Polski przez caly świat. Wspomnienia z 2 Korpusu, Warszawa 1970, s. 116-117.

57 Ibidem, s. 129. 
Italy Star (Gwiazda Włoch), War Medal 1939-1945 (Medal za Wojnę 1939-1945), Defence Medal (Medal Obrony). Zmarł w Manchesterze 9 kwietnia 2018 roku $^{58}$.

Emir Bajraszewski osiadł w Londynie. Kierował Gminą Muzułmanów Polskich istniejącą tam od 1947 roku. Redagował „Komunikat (Z Urzędu Imama Wojskowego)” i „Głos z Minaretu”. Zmarł w USA, w Denville, w stanie New Jersey, 6 stycznia 1996 roku ${ }^{59}$.

Ibrahim Bajraszewski powrócił do kraju w 1950 roku. W okresie rządów Bolesława Bieruta został aresztowany i skazany na 5 lat więzienia. Kierował jednym ze stołecznych przedsiębiorstw handlowych. W 1964 i 1978 roku przetrzymywano go w więzieniu bez wyroku. W 1992 roku został awansowany na kapitana ${ }^{60}$.

Abdul Hamid Churamowicz zamieszkał wraz z synem w Londynie. Zarabiał na życie jako kelner. Został odznaczony Krzyżem Walecznych i Złotym Krzyżem Zasługi. Umarł 13 grudnia 1955 roku, prawdopodobnie w Brookwood koło Londynu, gdzie spoczywają jego szczątki ${ }^{61}$.

Por. Dżennet Dżabagi-Skibniewska przeszła przez PKPR. W 1947 roku wróciła do kraju. Mieszkała w Gdyni i Wejherowie. Pracowała jako szwaczka i hafciarka w Spółdzielni Inwalidów „Bałtyk” w Gdańsku, Zrzeszeniu Hałupników i Twórców Ludowych "Artregion” w Wejherowie i „Fotopamie”. Była również ławnikiem Sądu Rejonowego w Gdańsku. Po rozwodzie z Janem Skibniewskim zawarła małżeństwo z Marianem Wolframem, weteranem $2 \mathrm{KP}$, z którym miała dwie córki (Danutę i Krystynę). W okresie stalinowskim była nękana przez UB. Po 1956 roku należała do Związku Bojowników o Wolność i Demokrację (ZBOWiD). Zmarła 17 maja 1992 roku w Groznym ${ }^{62}$.

Płk Veli Bek Jedigar wyjechał do Wielkiej Brytanii, w 1949 roku zaś emigrował do Argentyny. Pracował tam jako tragarz w porcie, następnie jako robotnik w fabryce wyrobów włókienniczych, przewodniczył Samodzielnemu Kołu Armii Krajowej i Sekcji Koła 7 Pułku Ułanów, został wiceprezesem Organizacji Ujarzmionych Narodów „Liberación Europea”, działał również w Związku Kaukazczyków. Owdowiał w 1953 roku i samotnie wychowywał jedynaczkę, Zulejhę Hanum (ur. 1942). Został odznaczony Krzyżem Walecznych, Złotym Krzyżem Zasługi z Mieczami, dwukrotnie Złotym Krzyżem Zasługi, Krzyżem AK. Zmarł na zawał serca 13 grudnia 1971 roku w Buenos Aires ${ }^{63}$.

${ }^{58}$ M. Abramowicz, op. cit., s. 123-144; 1 Pułk ułanów Krechowieckich. Kopie. Spis oficerów i ułanów 1939-'46, PISM, kol. 554/IV.5; Tatarzy w stużbie Polsce..., s. 44-45.

59 „Komunikat (Z Urzędu Imama Wojskowego)” 1948, nr 1, s. 1, 2, 6, PISM, A.II.E/1471; Słownik biograficzny Tatarów..., s. 45.

60 M. Borkowski, op. cit.; Tatarzy w stużbie Polsce..., s. 28, 61; B. Bratbak, op. cit. Ten ostatni podaje, że chociaż I. Bajraszewskiego wielokrotnie zatrzymywano i pozbawiano wolności, niekiedy na wiele miesięcy, nigdy nie stanął przed sądem.

61 Biblioteka POSK, „teka Jeżewskiego”; „Dziennik Polski i Dziennik Żołnierza” 1955, nr 308, s. 4.

62 Słownik biograficzny Tatarów..., s. 62-63; T. Zaniewska, op. cit., s. 126-153. Jej syn, Aleksander Al-Murat Skibniewski, twierdzi, że jej grób przeniesiono do Nasyr Kurt, dzielnicy Nazrania w Inguszetii, prof. Teresa Zaniewska zaś pisze, że został zniszczony podczas rosyjsko-czeczeńskich walk o Grozny w 1994 roku.

63 „Dziennik Polski i Dziennik Żołnierza” 1972, nr 7, s. 4. 
Majram Bek Margoti, Umasz Jusow i Hamid Korchmaz wstąpili do PKPR, tak jak zapewne Abu Bekir Jakubowski i Jan Szehidewicz, skoro wnioski o awans dwu ostatnich na podporuczników pochodzą — odpowiednio - z 23 i 4 czerwca 1947 roku. Nie wiadomo, co się działo z nimi po jego likwidacji ${ }^{64}$.

Mahmet Mucharski powrócił do kraju. Zamieszkał wraz z synem Konstantym w Gdańsku. Żona wraz z córką Marią pozostały w ZSRR (losów ich trzeciego dziecka nie znam). Pracował w spółdzielni garbarskiej. Amputowano mu nogi. Odznaczony Krzyżem Walecznych (1945), Gwiazdą za Wojnę 1939-1945, Gwiazdą Italii, Defence Medal (1947). Zmarł 15 kwietnia 1976 roku w Gdańsku ${ }^{65}$.

Dr Stefan Murza-Murzicz osiadł wraz żoną i córką Żanną w Londynie. Działał w Związku Lekarzy Polskich w Imperium Brytyjskim i Gminie Muzułmanów Polski. Zmarł w Londynie 29 maja 1978 roku $^{66}$. Dr Helena Murza-Murzicz-Teiseris (ostatni człon nazwiska zapewne przyjęty po mężu) pracowała jako lekarz w Centrum Geriatrycznym w Nowym Jorku. Zmarła w New Jersey w USA 27 stycznia 1977 roku ${ }^{67}$.

Ppor. Jakub Szehidewicz osiedlił się w 1947 roku wraz z rodziną w Wielkiej Brytanii. Zmarł dwa lata później na nowotwór wątroby ${ }^{68}$. Jego syn, Fuad, w 1952 roku ukończył roczny kurs uzupełniający chemii w Technical College w Nottingham, w 1973 roku zaś dwuletnie Studium Nauk Polityczno-Wojskowych na Polskim Uniwersytecie na Obczyźnie (PUNO) w Londynie. Pracował jako asystent laboratoryjny w Nottingham. W czasie wojny ożenił się z Danutą, miał dwoje dzieci (Bogusława i Ewę-Mirosławę) i troje wnuków. Awansowany przez Naczelnego Wodza i Prezydentów RP na Wychodźstwie: 1 kwietnia 1945 roku na podporucznika, 1 stycznia 1962 roku na porucznika, 15 sierpnia 1965 roku na kapitana, 12 października 1971 roku na majora, w 1990 roku na podpułkownika. Został odznaczony Krzyżem Walecznych (1945), Medalem Wojska (1945), Krzyżem Monte Cassino (1945), The Defense Medal (1945), Italy Star (1945), War Star (1945) i The War Medal (1945), Srebrnym Krzyżem Zasługi (1967), Medalem ZHP Monte Cassino (1969), medalami Skarbu Narodowego: Brązowym (1973), Srebrnym (1974) i Złotym (dwukrotnie, 1974 i 1983), Złotym Krzyżem Zasługi (dwukrotnie, 1975 i 1978), Krzyżem Pamiątkowym 5 DP (1982), Krzyżem Kawalerski Orderu Odrodzenia Polski (1983). Był członkiem Rady Narodowej przy Rządzie RP na Uchodźstwie. Działał między innymi w Kole Stowarzyszenia Polskich Kombatantów (SPK) nr 465 w Nottingham w Wielkiej Brytanii. Zmarł tamże 28 sierpnia 2004 roku ${ }^{69}$.

64 P. Adamczewski, op. cit.

65 Słownik biograficzny Tatarów..., s. 118-119.

66 „Dziennik Polski i Dziennik Żołnierza” 1978, nr 138, s. 4; Do Pana Ministra Spraw Zagranicznych. Londyn 15.10.47, PISM, A.II.E/1471; Spis imienny lekarzy..., Stefan Murza-Murzicz. Deklaracja...

67 „Dziennik Polski i Dziennik Żołnierza” 25.02.1977, nr 47, s. 44.

68 Słownik biograficzny Tatarów..., s. 180-181.

69 Ibidem, s. 177-178; „Tydzień Polski” (dodatek do „Dziennika Polskiego i Dziennika Żołnierza”) 2004, nr 36, s. 23. W Słowniku biograficznym Tatarów polskich podano jako datę jego awansu na podporucznika 30 marca 1945 roku (rozbieżność ta może wynikać z różnych dat wydania decyzji i jej wejścia w życie), a także mylnie określono datę jego zgonu na 6 września 2004 roku. 
Mjr Husein Kumuz wydawał w Monachium w języku angielskim czasopismo „Kaukaz”. Po przeniesieniu się do Wielkiej Brytanii został członkiem Rady i Prezydium Instytutu Wschodniego „Reduta”. Mieszkał w Londynie. Podróżował po krajach Bliskiego Wschodu. Prawdopodobnie podjął współpracę z MI6 (wywiadem brytyjskim). Zmarł w Brighton w grudniu 1964 roku $^{70}$.

\section{Podsumowanie}

Z zachowanych źródeł i opracowań wynika, że w PSZ służyło 39 muzułmanów, w tym 36 w 2 KP, 4 w JWŚW i 3 w innych jednostkach (Samodzielnej Brygadzie Strzelców Podhalańskich i Polskich Siłach Powietrznych). Większość z nich stanowili Tatarzy polscy urodzeni w województwach wileńskim i nowogródzkim, chociaż zdarzali się wśród nich ludzie innych narodowości (na przykład awarskiej, azerskiej, czerkieskiej), głównie pochodzący z Kaukazu. Prawdopodobnie większość z nich miała wykształcenie niepełne podstawowe i trudniła się przed wojną rolnictwem, ale część ukończyła studia, między innymi lekarskie, prawnicze, wojskowe. Do PSZ zaciągnęli się ze względu na wielowiekowe zamieszkiwanie ich przodków na obszarze państwa polsko-litewskiego, skutkujące mniej lub dalej posuniętą polonizacją, niechęć wobec Rosji i Rosjan, antykomunizm, życzliwe nastawienie dowództwa oraz rządu polskiego na wychodźstwie wobec mniejszości narodowych i wyznaniowych, a także żywe wśród niektórych polskich polityków emigracyjnych idee prometejskie zakładające wykorzystanie ludów kaukaskich przeciw ZSRR w interesie Polski. Trzech członków PSZ wyznających islam poniosło śmierć w wyniku walk. Większość z tych, którzy przeżyli wojnę, zmarła poza granicami Polski.

\section{Bibliografia}

Abramowicz M., Droga mojego życia. Ostatni ułan Rzeczpospolitej, Białystok 1438/2016.

Adamczewski P., Listy dotyczące osób pochodzenia kaukaskiego służacych $w$ Wojsku Polskim i działaczy ruchu prometejskiego, przechowywane $w$ polskich archiwach $w$ Londynie, http://dx.doi.org/10.12775/ SDR.2015.2.08 (dostęp: 10.02.2018).

Anders W., Bez ostatniego rozdziału. Wspomnienia z lat 1939-1946, Lublin 1995.

Arcybiskup generał brygady Sawa (Sowietow), red. K. Filipow, A. Suchcitz, Białystok-Warszawa 1997.

Berger R., Z listów do Macieja (Musy) Konopackiego, „Rocznik Tatarów Polskich. Czasopismo naukowe i literacko-społeczne poświęcone historii, kulturze oraz teraźniejszości Tatarów w Polsce i Europie Środkowo-Wschodniej” 2 (16), 2015 (1436/37), http://bibliotekatatarska.pl/rocznik-tatarow-polskich/ (dostęp: 27.11.2019).

Biegański W., Polskie Siły Zbrojne na Zachodzie 1939-1945, Warszawa 1990.

Biegański W., Wojsko Polskie we Francji 1939-1940, Warszawa 1967.

Bielawski J., Keler J., Kiryłowicz S., Kotański W., Potkowski E., Słuszkiewicz E., Szymański E., Tyloch W., Wierusz Kowalski J., Religie uniwersalistyczne. Zarys dziejów, Warszawa 1982.

70 CIA, ASSESMENT REPORT. Tscherim Soobzokov. 20-25 February 1956, s. 23, https://www.cia.gov/ library/readingroom/docs/SOOBZOKOV,\%20TSCHERIM\%20\%20\%20VOL.\%201_0138.pdf (dostęp: 24.03.2019); W. Romanow-Głowacki, op. cit., s. 4. 
Bohdanowicz L., The Muslims in Poland. Their origin, history, and cultural life, „Journal of the Royal Asiatic Society" October 1942.

Bohdanowicz L., Polska i Rosja a świat muzułmański, Londyn 1949.

Borkowski M., Tatar i Viking w jednym stali domu, „Polska Zbrojna” 1992, nr 110 (412), dodatek „Magazyn Tygodniowy" nr 23 (86).

Bratbak B., Tatar walczacy o Narvik, przeł. E. Hygen, PISM A XII 85/130/171, k. 1-10.

Buliński R., Rodzina Dżabagi - tułaczy los emigrantów kaukaskich, http://www.jpilsudski.org/component/ k2/item/2441-rodzina-dzabagi-tulaczy-los-emigrantow-kaukaskich (dostęp: 25.03.2019).

CIA, ASSESMENT REPORT. Tscherim Soobzokov. 20-25 February 1956, https://www.cia.gov/library/readingroom/docs/SOOBZOKOV,\%20TSCHERIM\%20\%20\%20VOL.\%201_0138.pdf (dostęp: 24.03.2019).

Cywilno-Wojskowa Parafia św. Cyryla i Metodego we Wrocławiu. Duchowieństwo. Ks. mitrat płk dr Eugeniusz Bójko, http://cerkiewpiaski.wroclaw.pl/?page_id=141 (dostęp: 24.03.2019).

Davies N., Szlak nadziei. Armia Andersa. Marsz przez trzy kontynenty, przeł. A. Zych, I. Zych, Izabelin-Warszawa 2015.

„Dziennnik Polski i Dziennik Żołnierza” 1955, nr 308; 1958, nr 105; nr 111; nr 114; 1959, nr 102; 1972, nr 7; 1977, nr 47; 1978, nr 138; 1981, nr 260; 2004, nr 36.

Filipow K., Suchcitz A., Arcybiskup generał brygady Sawa (Sowietow), Białystok-Warszawa 1997.

Encyklopedia II wojny światowej, red. K. Sobczak et al., Warszawa 1975.

Encyklopedia katolicka, t. 5, Lublin 1989; t. 18, Lublin 2013, t. 19, Lublin 2014.

Encyklopedia PWN, https://encyklopedia.pwn.pl (dostęp: 27.11.2019).

Hordejuk S., Mahomet Obuchowski (1898-1934). Wspomnienie w 80. rocznicę śmierci, „Życie Tatarskie” 2014, nr 40 (117).

Jackiewicz B., Campana G., Loreto, Loreto: il cimitero militare polacco, Falconara M.ma (An) 2007.

Jedigar-Kalinovska Z.H., Veli Bek Jedigar, http://www.polonia-baku.org/pl/losy.phtml\#jedigar (dostęp: 3.03.2019).

„Journal of the Royal Asiatic Society” 1942.

Juchnowski J., Kalicki W., Tomaszewski J., Polska myśl polityczna XX wieku. Wybór tekstów źródłowych z komentarzem, t. 1. Od końca XIX wieku do 1939 r., Legnica 2003.

Kłaczkow J., Na emigracji. Losy polskiego wychodźstwa ewangelickiego w XX wieku, Toruń 2013.

„Komunikat (Z Urzędu Imama Wojskowego)” 1948, nr 1; nr 2.

Koran, przeł. J. Bielawski, Warszawa 1986.

Kryska-Karski K., Żurawski S., Generałowie Polski niepodległej, Warszawa 1991.

Krzystek A., Krzystek T.J., Polskie Siły Powietrzne Wielkiej Brytanii w latach 1940-1947 łacznie z Pomocnicza Lotnicza Stużba Kobiet (PLSK-WAAF), Sandomierz 2012.

Medyna P., Do Polski przez caly świat. Wspomnienia z 2 Korpusu, Warszawa 1970.

Miśkiewicz A., Tatarzy polscy 1918-1939, Warszawa 1990.

Niebieska Eskadra, https://niebieskaeskadra.pl/ (dostęp: 9.02.2019).

Panas H., Jak mi było u Andersa, Warszawa 1988.

PISM (Instytut Polski i Muzeum im. gen. Władysława Sikorskiego w Londynie, the Polish Institute and Sikorski Museum in London), archiwum.

Polski Cmentarz w Bolonii, http://www.polskicmentarzbolonia.pl/pl/lista-pochowanych-bolonia/cart/1456/ jakub-jakubowski.html (dostęp: 19.02.2019).

Polskie Cmentarze we Włoszech, http://polskiecmentarzewewloszech.eu/pl/ (dostęp: 25.03.2019).

„Polska Zbrojna” 1992, nr 110.

POSK (Polski Ośrodek Społeczno-Kulturalny), „teka Jeżewskiego”.

Prawosławny Ordynariat Wojska Polskiego. Historia, http://prawoslawnyordynariat.wp.mil.pl/pl/18.html (dostęp: 24.03.2019).

Przewodnik po polskich cmentarzach wojennych we Włoszech. Monte Cassino, Loreto, Loreto, Casamassima, oprac. o. A. Struziński OP, Warszawa 1994.

Religie Wschodu i Zachodu. Wybór tekstów źródłowych, red. K. Banek, Warszawa 1991. 
Romanow-Głowacki W., Mjr. Huseyin Kumuz, „Dziennik Polski i Dziennik Żołnierza” 1965, nr 3.

Romanowicz J., Organizacja Polskiej Marynarki Wojennej we Francji i w Wielkiej Brytanii w latach 19391947, „Studia Historyczno-Wojskowe” 13 (64), 2012, nr 2 (240), http://bazhum.muzhp.pl/czasopismo /120/?idno=4477 (dostęp: 25.03.2019).

Słownik Biograficzny Tatarów Polskich, red. A. Miśkiewicz, Białystok 1438/2016.

Szmagier K., Generał Anders i jego żołnierze, Warszawa-Łódź 1993.

Tatarzy w służbie Polsce 1918-2018, red. B. Pawlic-Miśkiewicz, M. Çaxarxan Czachorowski, Białystok $1440 / 2018$.

Terlecki O., Generał Sikorski, t. 1, Kraków 1981.

Tyszkiewicz J., Tatarzy w Polsce i Europie. Fragmenty dziejów, Pułtusk 2009.

Tyszkiewicz J., Z historii Tatarów polskich 1794-1944, Pułtusk 2002.

Wąs A. SVD, Apostazja w islamie, https://religie.wiara.pl/doc/496521.Apostazja-w-islamie (dostęp: 4.03.2019).

Wąs A. SVD, Zakaz spożywania alkoholu, https://religie.wiara.pl/doc/497096.Zakaz-spozywania-alkoholu\# (dostęp: 8.02.2019).

Werra Z., Działalność duszpasterska w 2. Korpusie Polskich Sił Zbrojnych na Zachodzie gen. Władysława Andersa 1941-1947, Warszawa 2009.

Zaniewska T., Dżennet znaczy raj, Białystok 2002.

„Życie Tatarskie” 2014, nr 40 (117).

\section{Muslims in the Polish Armed Forces in the West}

Keywords: Muslims, Polish Armed Forces in the West, Second Polish Corps in Italy, Polish Air Force, Second World War, Polish Tatars

Summary

The Polish Armed Forces in the West had already begun to be formed in France in September 1939. From the beginning not only Roman Catholics but also representatives of different religious minorities living in the Second Republic of Poland joined it. In the Second Polish Corps in Italy, commanded by General Władysław Anders, 36 Muslims were serving in September 1945. At least 3 persons belonging to other military units of the Polish Armed Forces in the West were Muslims. In the text, I try to give as far as possible, the full economic and social characteristics of Muslims serving there. 